\title{
PENGARUH PENERAPAN METODE PROBLEM SOLVING TERHADAP MOTIVASI BELAJAR SISWA DALAM MATA PELAJARAN IPS KELAS IV MI PUI CIKASO KECAMATAN KRAMATMULYA KABUPATEN KUNINGAN
}

\author{
Oleh: \\ Dra. Mukhlisoh, M.Pd. \\ Siti Aisah
}

\begin{abstract}
Abstrak
Berdasarkan hasil observasi yang penulis lakukan di MI PUI Cikaso Kecamatan Kramatmulya Kabupaten Kuningan, diketahui bahwa dijumpai berbagai masalah salah satunya motivasi belajar siswa pada mata pelajaran IPS masih rendah di karenakan proses pembelajarannya yang masih berpusat pada guru dan siswa hanya mendengarkan materi yang diberikannya. Hal ini disebabkan pembelajaran IPS belum menggunakan metode yang sesuai dengan proses pembelajaran. Sehingga dalam penelitian ini dilatarbelakangi ketertarikan peneliti untuk menggunakan metode problem solving pada proses pembelajaran IPS.

Penelitian ini bertujuan untuk mengetahui : 1) Untuk mengetahui penerapan metode problem solving dalam pembelajaran IPS. 2) Untuk mengetahui motivasi belajar siswa dalam pembelajaran IPS. 3) Untuk mengetahui pengaruh metode problem solving terhadap motivasi belajar siswa dalam pembelajaran IPS.

Metode penelitian ini adalah metode kuantitatif. Populasi dalam penelitian ini adalah seluruh siswa kelas IV MI PUI Cikaso Kecamatan Kramatmulya Kabupaten Kuningan tahun pelajaran 2013/2014 yang berjumlah 31 orang siswa. Pengambilan sampel dilakukan dengan teknik sampel jenuh, yaitu seluruh poopulasi dijadikan sebagai sampel. Untuk mengetahui motivasi belajat IPS pada pokok bahasan masalah sosial yang ada di sekitar kita, sedangkan untuk mengetahui pengaruh metode problem solving yaitu dengan menyebarkan angket kepada semua siswa kelas IV.

Berdasarkan hasil penelitian dari uji korelasi diketahui bahwa datanya menunjukan bahwa keadaan interpretasi dari hubungan Antara variabel $\mathrm{X}$ dan variaber $\mathrm{Y}$ mencapai 0,707 berarti memasuki kategori kuat karena terletak diantara rentan nilai 0,600 - 0,800. Dengan demikian dapat disimpulkan bahwa tarap korelasi Antara variabel $\mathrm{x}$ terhadap variabel y kuat, artinya penerapan metode problem solving berpengaruh terhadap motivasi beajar siswa. Dari perhitungan analisis uji signifikansi korelasi Product Moment didapat nilai t hitung sebesar 7,612. Untuk mengetahui t tabel perlu diketahui $\mathrm{dk}$ $=31-2=29$, maka diperoleh $\mathrm{t}$ tabel $=5 \%$ sebesar 2,045 dan untuk $\mathrm{t}=1 \%$ sebesar 2,462 Maka, berdasarkan perhitungan tersebut diperoleh nilai $\mathrm{t}$ hitung $>\mathrm{t}$ tabel $(7,612>2,045)$ Jadi, pada taraf signifikansi 5\% hipotesis altenatif (Ha) diterima, sedangkan hipotesis nihil (Ho) ditolak, berarti terdapat pengaruh yang positif dan signifikan antara pendekatan problem solving terhadap motivasi belajar siswa.

Dengan demikian dapat disimpulkan bahwa dengan menggunakan metode problem solving memberikan pengaruh positif terhadap motivasi belajar siswa pada pembelajaran IPS di kelas IV MI PUI cikaso Kecamatan Kramatmulya Kabupaten Kuningan.
\end{abstract}




\section{A. Pendahuluan}

Pendidikan merupakan suatu proses dalam mengembangkan potensi sumber daya manusia guna mewujudkan insan pembangunan yang berbudaya dan bermartabat. Untuk mewujudkan hal tersebut tentunya diperlukan upayaupaya serta usaha yang maksimal. Melalui pendidikan dapat mengembangkan segala potensi yang dimiliki oleh peserta didik melalui proses pembelajaran. Untuk mewujudkan hal tersebut maka faktor guru memiliki peran sentral. Guru merupakan ujung tombak terdepan dalam menentukan keberhasilan peserta didik. Dalam rangka itu maka guru dituntut untuk memiliki ketrampilan serta kemampuan dalam mengelola proses pembelajaran secara profesional. Guru yang profesional akan tecermin dalam pelaksanaan pengabdian tugas-tugas yang ditandai dengan keahlian baik dalam materi maupun metode.

Model pembelajaran yang digunakan dalam proses belajar mengajar hendaknya memberikan hasil yang berguna bagi kehidupan dimasa mendatang dan dapat mencetak peserta didik yang berkualitas. Sejauh ini diketahui bahwa pengajaran yang dilakukan guru kebanyakan menggunakan metode pengajaran yang konvensional sehingga anak lebih bersifat pasif. Kegiatan pembelajaran terpusat pada guru sebagai pemberi informasi bahan pelajaran sehingga pembelajaran satu arah, guru tidak melibatkan siswa dalam pembelajaran kalaupun siswa diberi kesempatan untuk bertanya hanya sedikit saja yang melakukannya. Selain itu kurangnya pemahaman siswa dalam mengerjakan soal kasus. Siswa kurang sistematis dalam mengerjakan soal. Jawaban yang diberikan siswa membingungkan dan berputar putar. Model pembelajaran yang sesuai dengan penelitian ini adalah model pembelajaran problem solving. Model pembelajaran ini akan membantu siswa dalam mengerjakan soal secara sistematis, dengan penerapan model pembelajaran problem solving siswa diharapakan dapat membantu siswa untuk lebih aktif dan kreatif dalam menyelesaikan soal, menganalisa masalah dan dapat meningkatkan prestasi belajar. 


\section{B. Landasan Teori}

1. Motivasi

Pada dasarnya motivasi adalah suatu usaha yang disadari untuk menggerakkan, mengarahkan dan menjaga tingkah laku seseorang agar ia terdorong untuk bertindak melakukan sesuatu sehingga mencapai hasil atau tujuan tertentu (Sardiman, 2011: 75). Motivasi belajar adalah suatu perubahan tenaga di dalam diri seseorang (pribadi) yang ditandai dengan timbulnya perasaan dan reaksi untuk mencapai tujuan (Sardiman, 2011: 75).

Menurut Mc. Donald (dalam Sardiman 2011:73), motivasi adalah perubahan energi dalam diri seseorang yang ditandai dengan munculnya "feeling" dan didahului dengan tanggapan terhadap adanya tujuan. Dari pengertian yang dikemukakan Mc. Donald ini mengandung tiga elemen penting.

a. Bahwa motivasi itu mengawali terjadinya perubahan energi pada diri setiap individu manusia. Perkembangan motivasi akan membawa beberapa perubahan energi di dalam sistem "neurophysiological" yang ada pada organisme manusia. Karena menyangkut perubahan energi manusia, penampakkannya akan menyangkut kegiatan fisik manusia.

b. Motivasi ditandai dengan munculnya, rasa/feeling, afeksi seseorang. Dalam hal ini motivasi relevan dengan persoalan-persoalan kejiwaan, afeksi dan emosi yang dapat menentukan tingkah laku manusia.

c. Motivasi akan dirangsang karena adanya tujua. Jadi motivasi dalam hal ini sebenarnya merupakan respons dari suatu aksi, yakni tujuan. Motivasi memang muncul dari dalam diri manusia, tetapi kemunculannya karena terangsang oleh adanya unsur lain, dalam hal ini adalah tujuan.

Motivasi dapat juga dikatakan serangkaian usaha untuk menyediakan kondisi-kondisi tertentu, sehingga seseorang ingin melakukan sesuatu, dan bila ia tidak suka, maka akan berusaha untuk meniadakan atau mengelakkan perasaan tidak suka itu. Jadi motivasi itu dapat dirangsang 
oleh faktor dari luar tetapi motivasi itu adalah tumbuh di dalam diri seseorang. Dalam kegiatan belajar, motivasi dapat dikatakan sebagai keseluruhan daya penggerak di dalam diri siswa yang menimbulkan kegiatan belajar, yang menjamin kelangsungan dari kegiatan belajar dan yang memberikan arah pada kegiatan belajar, sehinga tujuan yang dikehendaki oleh subjek belajar itu dapat tercapai.

Beberapa teknik atau pendekatan untuk memotivasi siswa agar memiliki gairah dalam belajar, antara lain :

a. Berikan kepada siswa rasa puas untuk keberhasilan lebih lanjut.

b. Ciptakanlah suasana kelas yang menyenangkan.

c. Aturlah tempat duduk siswa secara bervariasi.

d. Pakailah metode penyampaian yang bervariasi sesuai dengan materi yang disajikan.

e. Kembangkan pengertian para siswa secara wajar.

f. Berikan komentar terhadap pekerjaan siswa.

2. Faktor yang Mempengaruhi Belajar

Menurut Soemanto (2003: 113) dalam belajar, banyak sekali faktor yang mempengaruhi belajar namun dari sekian banyaknya faktor yang mempengaruhi belajar, hanya dapat digolongkan menjadi tiga macam yaitu :

a. Faktor-faktor stimuli belajar

Stimuli belajar adalah segala hal di luar individu yang merangsang individu itu untuk mengadakan reaksi atau perubahan belajar, misalnya panjangnya bahan pelajaran, kesulitan bahan pelajaran, berartinya bahan pelajaran, berat ringannya tugas, suasana lingkungan eksternal.

b. Faktor-faktor metode belajar

Metode mengajar yang dipakai oleh guru sangat mempengaruhi metode belajar yang dipakai oleh siswa, maka metode yang dipakai oleh guru menimbulkan perbedaan yang berarti bagi proses belajar, misalnya tentang kegiatan berlatih atau praktek, menghafal atau mengingat, pengenalan tentang hasil-hasil belajar, bimbingan dalam belajar. 


\section{c. Faktor-faktor individual}

Faktor-faktor individual juga sangat besar pengaruhnya terhadap belajar seseorang, misalnya tentang kematangan individu, usia, perbedaan jenis kelamin, pengalaman sebelumnya, motivasi, kondisi kesehatan.

3. Metode Pembelajaran

Metode pembelajaran adalah cara yang digunakan guru untuk menyampaikan pelajaran kepada siswa. Karena penyampaian itu berlangsung dalam interaksi edukatif, metode pembelajaran dapat diartikan sebagai cara yang dipergunakan oleh guru dalam mengadakan hubungan dengan siswa pada saat berlangsungnya pengajaran. Dengan demikian, metode pembelajaran merupakan alat untuk menciptakan proses belajar mengajar.

Metode pembelajaran yang ditetapkan guru memungkinkan siswa banyak belajar proses (learning by process), bukan hanya belajar produk (learning by product). Belajar produk pada umumnya hanya menekankan pada segi kognitif, sedangkan belajar proses dapat memungkinkan tercapainya tujuan belajar dari segi kognitif, afektif (sikap) maupun psikomotor (keterampilan). Hal ini berarti peranan guru berubah, dari yang semula sebagai penyaji materi pembelajaran, menjadi pemberi pengaruh dan pemberi kemudahan untuk terjadinya proses belajar mengajar.

Metode pemecahan masalah adalah suatu cara menyajikan pelajaran dengan mendorong siswa untuk mencari dan memecahkan suatu masalah atau persoalan dalam rangka pencapaian tujuan pengajaran. (Hamdani, 2011:84). Prinsip dasar dalam metode ini adalah perlunya aktivitas dalam mempelajari sesuatu. Aktivitas siswa akan timbil jika guru menjelaskan manfaat bahan pelajaran bagi siswa dan masyarakat (Hamdani, 2011:84).

Metode pemecahan masalah (problem solving) merupakan metode dalam kegiatan pembelajaran dengan jalan melatih siswa menghadapi berbagai masalah, baik masalah pribadi maupun masalah kelompok untuk dipecahkan sendiri atau secara bersama-sama. Orientasi pembelajarannya 
adalah investigasi dan penemuan yang pada dasarnya adalah pemecahan masalah.

Keunggulan metode problem solving

a. Melatih siswa untuk mendesain suatu penemuan.

b. Berfikir dan bertindak kreatif.

c. Memecahkan masalah yang dihadapi secara realistis.

d. Mengidentifikasi dan melakukan penyelidikan.

e. Menafsirkan dan mengevaluasi hasil pengamatan.

f. Merangsang perkembangan kemajuan berfikir siswa untuk menyelesaikan masalah yang dihadapi dengan tepat.

g. Dapat membuat pendidikan sekolah lebih relevan dengan kehidupan, khususnya dunia kerja.

Semua metode mempunyai kelebihan dan kekurangannya tersendiri, begitu juga dengan metode problem solving. Metode ini memiliki kelebihan dan kekurangannya, adapun kelebihan dan kekurangannya adalah sebagai berikut :

a. Kelebihan metode pemecahan masalah (Hamdani, 2011:86)

1) Melatih siswa untuk menghadapi problema atau situasi yang timbul secara spontan.

2) Siswa menjadi aktif dan berinisiatif serta bertanggung jawab.

3) Pendidikan di sekolah relevan dengan kehidupan.

4) Sukar sekali menentukan masalah yang benar-benar cocok dengan tingkat kemampuan siswa.

b. Kekurangan metode pemecahan masalah (Hamdani, 2011:186)

1) Memerlukan waktu yang lama, artinya memerlukan alokasi waktu yang lebih panjang dibandingkan dengan metode pembelajaran yang lain.

2) Siswa yang pasif dan malas akan tertinggal.

3) Sukar sekali untuk mengorganisasikan bahan pelajaran.

Dalam pembelajaran Ilmu Pengetahuan Sosial (IPS) aspek-aspek ilmu pengetahuan harus mendapat penekanan, terutama pada jenjang pendidikan dasar. Karena itu, untuk mempersiapkan siswa menjadi warga negara yang mampu berpikir kritis, kreatif dan bertanggung jawab, perlu dilakukan pembinaannya semenjak kecil yaitu semenjak mereka duduk 
pada bangku SD/MI. Pada jenjang pendidikan ini, keterampilan intelektual, sosial dan ketrampilan bekerjasama dalam kelompok serta kemampuan untuk nmelakukan hubungan inter-personal harus dikembangkan secara tepat dan seimbang.

Selanjutnya, dalam pengajian IPS yang dijadikan patokan dan tolak ukur utama adalah tujuan. Oleh karena itu keberhasilan pengajaran IPS juga diukur dengan seberapa jauh tujuan yang telah dirumuskan dapat dicapai dalam pelajaran. Hal ini menunjukkan adanya keterkaitan yang erat antara tujuan yang dicapai dengan apa yang akan diajarkan.

Sehubungan dengan itu, maka dalam memilih materi kurikulum yang dikembangkan dari berbagai disiplin ilmu perlu diperhitungkan keterkaitannya dengan tujuan. Semakin erat keterkaitannya semakin besar materi itu dipilih sebagai materi kurikulum. IPS memiliki cakupan materi yanng cukup luas yang disusun dengan menggunakan concep of expanding communities atau expanding horizons approach, yaitu bahan pelajaran disusun mulai dari yang bersumber pada lingkungan terdekat sampai yang jauh.

\section{Metode Penelitian}

Penelitian ini dilaksanakan pada semester 2 (genap) tahun pelajaran 2013/2014 yang berlangsung pada tanggal 22 Mei - 31 Juli 2014. Rincian waktu pelaksanaan penelitian sebagai berikut:

Waktu Pelaksanaan Penelitian

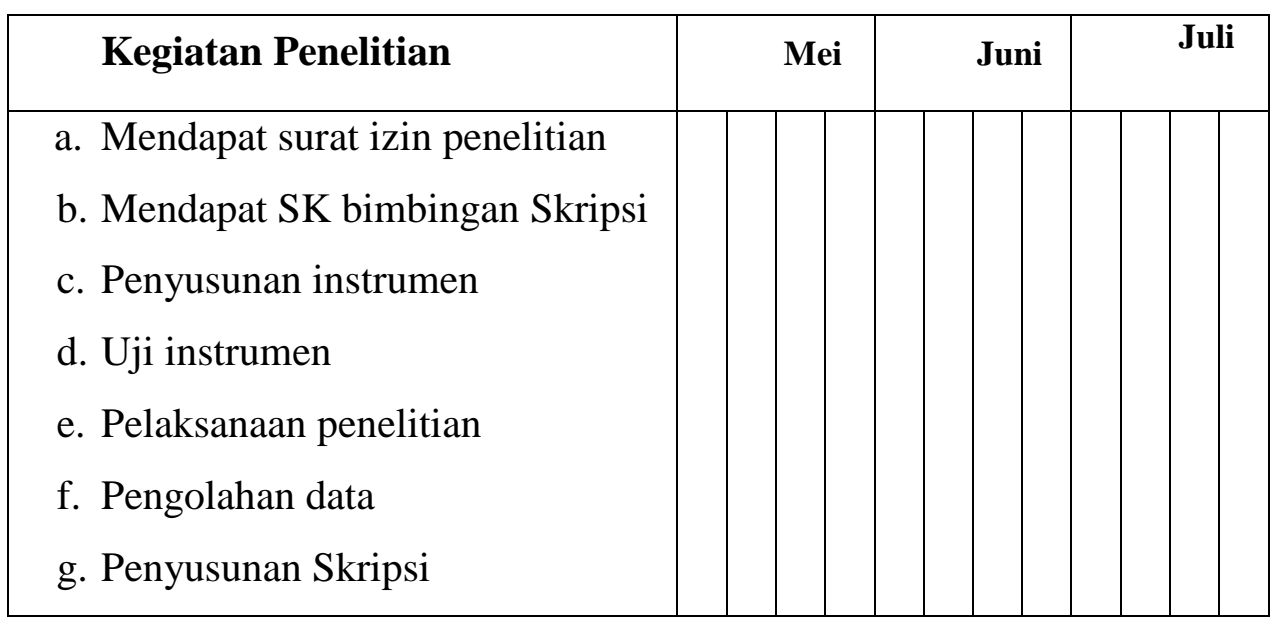




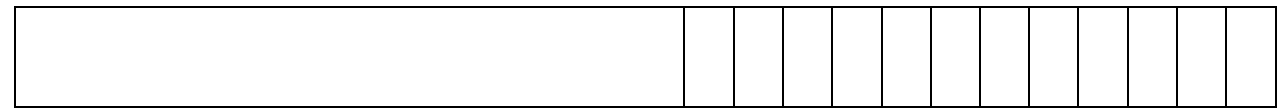

Peneliti akan mengambil tempat di MI PUI Cikaso kecamatan Kramatmulya kabupaten Kuningan. Terdiri dari 17 orang laki-laki dan 14 orang perempuan di kelas IV MI PUI Cikaso.

Menurut Arikunto (2010: 192) angket atau kuesioner adalah sejumlah pertanyaan tertulis yang digunakan untuk memperoleh informasi dari responden dalam arti laporan tentang pribadinya atau hal-hal yang diketahui oleh peneliti.

Angket dapat dibeda-bedakan atas beberapa jenis, tergantung pada sudut pandang :

1. Dipandang dari cara menjawab, maka ada :

a. Angket terbuka, yang memberi kesempatan kepada responsden untuk menjawab dengan kalimatnya sendiri.

b. Angket tertutup, yang sudah disediakan jawabannya sehingga responden tinggal memilih.

2. Dipandang dari jawaban yang diberikan ada:

a. Angket langsung, yaitu responden menjawab tentang dirinya.

b. Angket tidak langsung, yaitu jika responden menjawab tentang orang lain.

c. Dipandang dari bentuknya maka ada :

1) Angket pilihan ganda, yang dimaksud adalah sama dengan angket tertutup.

2) Angket isian, yang dimaksud adalah angket terbuka.

3) Check list, sebuah daftar di mana responden tinggal membubuhkan tanda check $(\sqrt{ })$ pada kolom yang sesuai.

4) Rating-scale, (skala bertingkat), yaitu sebuah pernyataan diikuti oleh kolom-kolom yang menunjukkan tingkatan-tingkatan, misalnya mulai dari sangat setuju sampai ke sangat tidak setuju.

Keuntungan angket :

a. Tidak memerlukan hadirnya peneliti. 
b. Dapat dibagikan secara serentak kepada banyak responden.

c. Dapat dijawab oleh responden menurut kecepatannya masingmasing dan menurut waktu senggang responden.

d. Dapat dibuat anonim sehingga responden bebas, jujur dan tidak malu-malu menjawab.

e. Dapat dibuat terstandar sehingga bagi semua responden dapat diberi pertanyaan yang benar-benar sama.

Kelemahan angket :

a. Responden sering tidak teliti dalam menjawab sehingga ada pertanyaan yang terlewati tidak dijawab, padahal sukar diulang untuk diberikan kembali kepadanya.

b. Sering sukar dicari validitasnya.

c. Walaupun dibuat anonim, kadang-kadang responden dengan sengaja memberikan jawaban yang tidak betul atau tidak jujur.

Untuk mengatasi kelemahan-kelemahan angket terutama b dan c, peneliti perlu menyilang jawaban responden dengan data yang diperoleh melalui metode lain. Istilahnya, peneliti mengatakan cross-check.

Analisa angket dalam penelitian digunakan untuk mengetahui dan menggambarkan mengenai keadaan variabel motivasi belajar. Adapun langkah analisis diskriptif prosentase adalah memberikan skor terhadap jawaban responden dengan ketentuan :

1. Skor pernyataan positif

a) Untuk jawaban selalu diberi skor 4

b) Untuk jawaban sering diberi skor 3

c) Untuk jawaban kadang-kadang diberi skor 2

d) Untuk jawaban tidak pernah diberi skor 1

2. Skor pernyataan negatif

a) Untuk jawaban selalu diberi skor 1

b) Untuk jawaban sering diberi skor 2

c) Untuk jawaban kadang-kadang diberi skor 3

d) Untuk jawaban tidak pernah diberi skor 4 


\section{Hasil Penelitian}

Hasil rata-rata prosentase angket penerapan metode problem solving di kelas IV MI PUI Cikaso Kecamatan Kramatmulya Kabupaten Kuningan yang menjawab "sangat setuju" ada 34\%, yang menjawab "setuju" 24\%, yang menjawab "kurang setuju" 29\%, yang menjawab "Tidak setuju” $13 \%$.

Untuk memperoleh data tentang penerapan metode problem solving peneliti menggunakan angket yang terdiri dari 20 item pernyataan. Sedangkan hasil rata-rata prosentase angket motivasi belajar di kelas IV MI PUI Cikaso Kecamatan Kramatmulya Kabupaten Kuningan yang menjawab "sangat setuju" ada $42 \%$, yang menjawab "setuju" $22 \%$, yang menjawab "kurang setuju" 25\%, yang menjawab "Tidak setuju" $11 \%$.

Untuk memperoleh data mengenai Pengaruh Penerapan Metode Problem Solving Terhadap Motivasi Beajar Siswa Dalam Mata Pelajaran IPS Di Kelas IV MI PUI Cikaso Kecamatan Kramatmulya Kabupaten Kuningan. Penulis terlebih dahulu mengadakan penyesuaian variabel $\mathrm{X}$ dan variabel $\mathrm{Y}$, yang dalam hal ini variabel X yaitu Penerapan Metode Problem Solving, sedangkan variabel Y yaitu Motivasi Beajar Siswa, penulis menggunakan rumus korelasi product moment sebagai berikut :

$$
r_{x y}=\frac{N \sum X Y-\left(\sum X\right)\left(\sum Y\right)}{\sqrt{\left\{N \sum X^{2}-\left(\sum X\right)^{2}\right\}\left\{N \sum Y^{2}-\left(\sum Y\right)^{2}\right\}}}
$$

keterangan :

$$
\begin{aligned}
& r_{\mathrm{xy}}=\text { Koefisien korelasi antara variabel } \mathrm{X} \text { dan variabel } \mathrm{Y} \\
& \mathrm{X}=\begin{array}{l}
\text { Nilai variabel } \mathrm{X} \text { (motivasi siswa dalam mengikuti } \\
\text { kegiatanpramuka) }
\end{array} \\
& \mathrm{Y}=\text { Nilai variabel } \mathrm{Y} \text { (kedisiplinan belajar) }
\end{aligned}
$$




$$
\begin{aligned}
& \mathrm{X}^{2}=\text { Nilai variable } \mathrm{X} \text { yang dikuadratkan } \\
& \mathrm{Y}^{2}=\text { Nilai variable } \mathrm{Y} \text { yang dikuadratkan } \\
& \mathrm{N}=\text { Jumlah sampel yang menjadi obyek peneliti }
\end{aligned}
$$

Hasil dari perhitungan, menunjukan bahwa keadaan interpretasi dari hubungan Antara variabel $\mathrm{X}$ dan variaber $\mathrm{Y}$ mencapai 0,707 berarti memasuki kategori kuat karena terletak diantara rentan nilai 0,600 - 0,800. Dengan demikian dapat disimpulkan bahwa tarap korelasi Antara variabel X terhadap variabel Y kuat, artinya penerapan metode problem solving berpengaruh terhadap motivasi beajar siswa dalam mata pelajaran IPS Di Kelas IV MI PUI Cikaso Kecamatan Kramatmulya Kabupaten Kuningan.

Uji hipotesis dilakukan untuk mengetahui signifikan tidaknya pengaruh antara variabel tersebut. Untuk menguji hipotesis digunakan koefisien korelasi product moment dengan uji t sebagai kriteria penolakan. Dalam penelitian ini, penulis menetapkan hipotesis sebagai berikut :

Ha : Terdapat pengaruh yang positif dan signifikan pendekatan problem solving terhadap hasil belajar siswa kelas IV MI PUI Cikaso Kecamatan Kramatmulya kabupaten Kuningan pada pokok bahasan masalah sosial.

Ho: Tidak terdapat pengaruh yang positif dan signifikan pendekatan problem solving terhadap hasil belajar siswa kelas IV MI PUI Cikaso Kecamatan Kramatmulya kabupaten Kuningan pada pokok bahasan masalah sosial.

Dari perhitungan didapat nilai $\mathrm{t}$ hitung sebesar 7,612. Untuk mengetahui $\mathrm{t}$ tabel perlu diketahui $\mathrm{dk}=31-2=29$, maka diperoleh $\mathrm{t}$ tabel $=$ $5 \%$ sebesar 2,045 dan untuk $\mathrm{t}=1 \%$ sebesar 2,462 Maka, berdasarkan perhitungan tersebut diperoleh nilai $t$ hitung $>\mathrm{t}$ tabel $(7,612>2,045) \mathrm{Jadi}$, pada taraf signifikansi 5\% hipotesis altenatif (Ha) diterima, sedangkan hipotesis nihil (Ho) ditolak, berarti terdapat pengaruh yang positif dan signifikan antara 
pendekatan problem solving terhadap motivasi belajar siswa.

Dengan menggunakan metode problem solving diharapkan dapat membantu siswa unuk meningkatkan keaktifan di dalam kelas dan dapat meningkatkan prestasi beajar siswa.

Motivasi belajar siswa dengan menggunakan meode problem solving dalam pembelajaran IPS adalah sangat penting dimana siswa akan lebih aktif dalam memecahkan masalah yang ada sehingga pembelajaran di kelas lebih bermanfaat bagi siswa dan gurunya. Model pembelajaran yang digunakan dalam proses belajar mengajar hendaknya memberikan hasil yang berguna bagi kehidupan dimasa mendatang dan dapat mencetak peserta didik yang berkualitas.

Terdapat pengaruh yang positif dan signifikan dalam menggunakan pendekatan problem solving terhadap hasil pembelajaran IPS di kelas. Sehingga dalam penggunaan metode ini siswa diharapkan lebih semangat dalam proses belajar mengajar sehingga mendapatkan nilai yang baik.

\section{E. Kesimpulan}

Dari hasil penelitian yang penulis lakukan mengenai "Pengaruh Penerapan Metode problem solving terhadap Motivasi Belajar Siswa Dalam Mata Pelajaran IPS kelas IV MI PUI Cikaso Kecamatan Kramatmulya Kabupaten Kuningan", maka dapat ditarik kesimpulan sebagai berikut :

1. Penerapan metode Problem Solving pada pelajaran IPS di kelas IV MI PUI Cikaso Kecamatan Kramatmulya Kabupaten Kuningan dikategorikan sedang karena hasil nilai rata-rata dari angket mencapai $58 \%$ pada interval $40-59$.

2. Motivasi belajar siswa di kelas IV MI PUI Cikaso Kecamatan Kramatmulya Kabupaten Kuningan dikategorikan kuat karena karena hasil nilai rata-rata dari angket mencapai $64 \%$ pada interval 60-79.

3. Setelah diketahui rata-rata dari masing-masing variabel maka langkah selanjutnya uji hipotesis dengan rumus korelasi product moment, dari 
analisis tersebut didapat nilai t hitung sebesar 7,612. Untuk mengetahui $\mathrm{t}$ tabel perlu diketahui $\mathrm{dk}=31-2=29$, maka diperoleh $\mathrm{t}$ tabel $=5 \%$ sebesar 2,045 dan untuk $\mathrm{t}=1 \%$ sebesar 2,462 Maka, berdasarkan perhitungan tersebut diperoleh nilai t hitung $>\mathrm{t}$ tabel $(7,612>2,045)$. Jadi, pada taraf signifikansi 5\% hipotesis altenatif (Ha) diterima, sedangkan hipotesis nihil (Ho) ditolak, artinya penerapan metode problem solving berpengaruh terhadap motivasi beajar siswa dalam mata pelajaran IPS Di Kelas IV MI PUI Cikaso Kecamatan Kramatmulya Kabupaten Kuningan. 


\section{DAFTAR PUSTAKA}

Abdurrahman, Mulyono. 2003. Pendidikan Bagi Anak Berkesulitan Mengajar. Jakarta: Rineka Cipta

Ali, Muhammad. 2008. Guru Dalam Proses Belajar Mengajar. Bandung: Sinar Baru Algensindo

Arikunto, Suharsimi. 2006. Penelitian Suatu Pendekatan Praktek. Jakarta : Rineka Cipta.

2010. Prosedur Penelitian Suatu Pendekatan Prakteik. Jakarta: PT Rineka Putra

Djamarah, Syaiful Bahri. 2008. Psikologi Belajar. Jakarta: Rineka Cipta.

Depdikbud. 1997. Kamus Besar Bahasa Indonesia edisi kedua. Jakarta: Depdikbud

Hake, Richard R. 1998. Journal: Analizing Change/Gain Scores USA: Departement of physics, Indiana University Woodhind Hills, Tersedia di : www. physics Indiana adu/sdi/AnalizingChange Gain.pdf Diakses 10 Juni2014.

Hakim, Thursan. 2001. Belajar Secara Efektif. Jakarta: Puspa Swara

Hamalik, Oemar. 2012. Psikologi Belajar Mengajar. Bandung: Sinar Baru Algensindo

2003. Prosedur Belajar Mengajar. Jakarta: Bumi Aksara

Hamdani. 2011. Strategi Belajar Mengajar. Bandung : CV Pustaka Setia.

Hasan, Iqbal. 2010. Analisis Data Penelitian dengan Statistik. Jakarta: Bumi Aksara

Ismail. 2003. Media Pembelajaran (Model-Model Pembelajaran). Jakarta: Direktorat Pendidikan Nasional.

Meltzer, David E. 2002. Journal: The relationship between mathematics preparation and conceptual learning gains in physics: a possible .hidden variable. in diagnostic pretest scores. Department of Physics and Astronomy, Iowa State University, Ames, Iowa 50011. Tersedia di: www. Physics, indiana.edu/sdi/AnalizingChange.gain.pdf Diakses 10 Juni 2014. 
Nashar. 2004. Peranan Motivasi dan Kemampuan Awal dalam Kegiatan Pembelajaran. Jakarta: Delia Press

Priyatno, Dwi. 2009. 5 Jam Belajar Olah Data Dengan SPSS 17. Yogyakarta : ANDI.

Purwanto, Ngalim. 1999. Psikologi Pendidikan. Bandung: Pustaka Setia

Riduwan. 2008. Belajar Mudah Penelitian Untuk Guru-Karyawan Dan Peneliti Pemula. Bandung : Alfabeta

Rusman. 2010. Model-model Pembelajaran Mngembangkan Profesionalisme Guru. Jakarta: PT Rajagrafindo Persada

Syaiful Bahri Djamara. 2006. Strategi Belajar Mengajar. Jakarta : Rineka Cipta

Sardiman. 2011. Interaksi dan Motivasi Belajar Mengajar. Jakarta: PT Rajagrafindo Persada

Slameto. 2002. Belajar dan Faktor-faktor yang Mempengaruhinya. Jakarta: Rinka Cipta

Soemanto, Wasty. 2003. Psikologi Pembelajarandan Pengajaran. Bandung: Pustaka Bani Quraisy

Subana, dkk. 2005. Statistik Pendidikan. Bandung: Pustaka Setia

Sudjana, Nana. 2011. Dasar-dasar Proses Belajar Mengajar. Bandung: Sinar Baru Algensindo

Sugiyono. 2013. Metode Penelitian Pendidikan. Bandung : ALFABETA. 2011. Statistik Untuk Penelitian. Bandung: Alfabeta

Sujana. 2000. Strategi Pembelajaran. Bandung: Falah Production

Surya, Muhammad. 2004. Psikologi Pembeljaran dan Pengajaran. Bandung: Pustaka Bani Quraisy

Uno, Hamjah. 2013. Teori Motivasi dan Pengukurannya. Jakarta: PT Bumi Aksara 